\title{
A technological and economic exploration of phosphate recovery from centralised sewage treatment in a transitioning economy context
}

\author{
Melissa KLN Sikosana'*, Dyllon G Randall ${ }^{2}$ and Harro von Blottnitz ${ }^{1}$ \\ 'Environmental \& Process Systems Engineering, Department of Chemical Engineering, University of Cape Town, Private Bag X3, Rondebosch, 7701, \\ South Africa \\ ${ }^{2}$ Water Research Group, Department of Civil Engineering, University of Cape Town, Private Bag X3, Rondebosch, 7701, South Africa
}

\begin{abstract}
Phosphate is one of the substances which wastewater treatment works (WWTW) have to lower in order to meet the South African regulatory discharge standard of $1 \mathrm{mg} / \mathrm{L}$. Wastewater is increasingly viewed as a 'water-carried waste', presenting opportunities for resource recovery. South Africa has commenced its transition to a low-carbon and resourceefficient economy, all whilst it struggles to provide universal access to basic needs and is faced with massive infrastructure maintenance as well as upgrading backlogs in the sanitation sector in particular. Although phosphate recovery methods exist, there is little evidence to indicate that these techniques would be economically viable or socially accepted in South Africa. This paper explores the potential for centralized recovery of nutrients, through the conceptual design and technoeconomic pre-feasibility assessment of two phosphate recovery options, at the largest WWTW in the Western Cape, South Africa. This assessment revealed that the digestate stream at the $200 \mathrm{ML} / \mathrm{d}$ Cape Flats WWTW (CFWWTW) has the potential to produce $\sim 470 \mathrm{~kg} / \mathrm{d}$ of struvite fertilizer, whilst recovering $4-8 \%$ of the plant's costs in 20 years. When contrasted with the more familiar, yet less sustainable, chemical precipitation process, low-grade and high-grade struvite production establishment costs are 10 and 25 times higher, respectively. Still, to reduce effluent phosphate loading to within regulated standards, the low-grade struvite production option at an estimated net present cost of R25.4 million over a 20 -year lifetime is more affordable than chemical precipitation at a net present cost of R51.2 million. Low-grade struvite production is thus concluded to be technically feasible and the economically most affordable option from a lifecycle-costs perspective. Although it is a simple process, it is not cheap. Municipalities will need to consider the lower operating costs, as well as the environmental benefit of producing a useful phosphate fertilizer, over the immediate capital investment, if they decide to install such an operation.
\end{abstract}

Keywords: nutrient recovery; struvite; techno-economic assessment; phosphate recovery; South Africa

\section{INTRODUCTION}

Wastewater is increasingly viewed as a 'water-carried waste', presenting opportunities for recovery of both nutrients and energy. Amongst the sewage-borne resources, phosphorus is an important, non-substitutable nutrient for all life forms, particularly in the growth of plants, and is therefore essential in ensuring universal food security (Liu et al., 2008; Kalmykova et al., 2012). Human activities have disturbed the natural phosphorus cycle and remain heavily dependent on mining of non-renewable rock phosphate. It is estimated that $78 \%$ to $90 \%$ of the global phosphate demand is directly attributed to the production of synthetic fertilizers and livestock feed additives in the agriculture industry (Liu et al., 2008; Kalmykova et al., 2012).

In tackling the growing global food crisis, it will be important to consider the quality and usefulness of the recovered phosphate product for potential agricultural use (Schröder, et al., 2009). Urine separation and sewage nutrient recovery technologies that yield high quality and useful products are being explored and implemented globally (Wilsenach, 2003; Ganrot, 2005; Etter, 2009; Kalmykova et al., 2012). Due to South Africa's sanitation and economic backlogs, it should be in the best interest of the South African society to not only treat the access to sanitation issue as a high priority, but to also consider the employment of such ecologically and economically sustainable

*To whom all correspondence should be addressed.

e-mail: sksmel001@myuct.ac.za

Received 8 April 2016; accepted in revised form 22 March 2017 sanitation solutions to meet future needs, as it strives to meet the Sustainable Development Goals.

Industrial and commercial uptake of technologies is hindered through inadequate development of problems within the technology transfer pipeline. Cultural and geographical influences on a technology's penetration into a new market are further complicated by perceived health and social risks, aspects of technology development that are often overlooked. Today, research has taken a turn to better understand and tackle these issues, as is shown by the development of holistic technology sustainability assessments demonstrated by Balkema (2002) and Muga and Mulchelci (2008). These frameworks are conceptual and have been applied to existing nutrient-recovery case studies, but are yet to be applied in the prefeasibility step of phosphate recovery techniques, let alone in the South African context. The need for a more holistic approach, which includes both a social and techno-economic assessment of potential technologies, has shaped the aims and methodology of our research on phosphate recovery (Sikosana et al., 2014).

It was thus an overarching objective of our research to determine whether phosphate recovery technologies are likely to produce a socially acceptable product and what determines their affordability. In this paper, we focus on the latter and present the techno-economic analysis of a case study, which demonstrates how a nutrient recovery process could be incorporated into a biological wastewater treatment works in South Africa. Links are made to our earlier social acceptability study (Sikosana et.al, 2014), which maps potential market avenues for recovered 
phosphate - an important factor used to determine both pricing and economic viability.

\section{BACKGROUND}

The sludge liquor stream in a biological WWTW with anaerobic digestion has been identified as one of the most promising points for nutrient recovery (Strom, 2006; Bilyk et al., 2011). In the South African context, and more specifically in the Western Cape, the $200 \mathrm{ML} / \mathrm{d}$ Cape Flats WWTW (CFWWTW) is a good example of a treatment facility in which such a phosphateenriched stream arises, and forms the basis of this technoeconomic analysis.

Mineral precipitation issues (mostly struvite) experienced at the CFWWTW, has led to the poor performance of the digestate centrifuge, as well as blockages in the Thermal Drying Plant pipeline. Batch dewatering may cause nutrient peaks and instability in secondary processes, hence causing effluent nutrient spikes and spontaneous struvite precipitation (Bilyk et al., 2011). Excess phosphorus in the waste activated sludge (WAS) as well as the loss of $\mathrm{CO}_{2}$ (which increases $\mathrm{pH}$ ) along the sludge treatment line, are the main causes of struvite precipitation (Van Rensburg et al., 2003). An additional nutrient sink would recover these excess nutrients and could mitigate blockages in the anaerobic digester's (AD) sludge centrifuge and pipeline. Therefore, this paper explores the technical and economic viability of applying a globally proven and advanced crystallisation technology at the CFWWTW to address this issue.

\section{Case studies: Ostara installation at Nansemond Treatment Plant (2010); Multiform Harvest at Yakima WWTW (2012)}

Ostara installation by Hampton Roads Sanitation District (HRDS), at the Nansemond Treatment Plant, Suffolk, Virginia, USA, and Multiform Harvest in Yakima WWTW, USA, provide commercial scale, crystallisation nutrient recovery technologies. Their installations have been shown to successfully treat the sludge liquor exiting anaerobic digester units at centralised WWTWs.

Ostara's Pearl Reactor installed at the HRDS Nansemond WWTP, Virginia, recovers-excess nutrients to help mitigate blockages in the digested sludge pipelines. This full-scale facility extracts up to $85 \%$ of the excess phosphates, as $1650 \mathrm{~kg} / \mathrm{d}$ highquality struvite, when operating at a maximum capacity of 416 $\mathrm{m}^{3} / \mathrm{d}$. The struvite is further processed and packaged on site, before it is sold by Ostara, under the brand name Crystal Green.

Similarly, the Multiform Harvest process installed at Yakima's $75 \mathrm{ML} / \mathrm{d}$ WWTW, comprises of conical fluidized bed reactors. Although a recovery of up to $90 \%$ of the excess phosphate is possible, the lack of a recycle stream and the short retention time results in $450 \mathrm{~kg} / \mathrm{d}$ of wet, powdery and low-grade fertilizer. In this case, the $830 \mathrm{~kL} / \mathrm{d}$ nutrient recovery facility, reduces the phosphate concentrations of the WWTW effluent entering the Yakima River to curb seasonal eutrophication. The Ostara set-up is illustrated in Fig. 1 and the two processes are compared in Table 1.

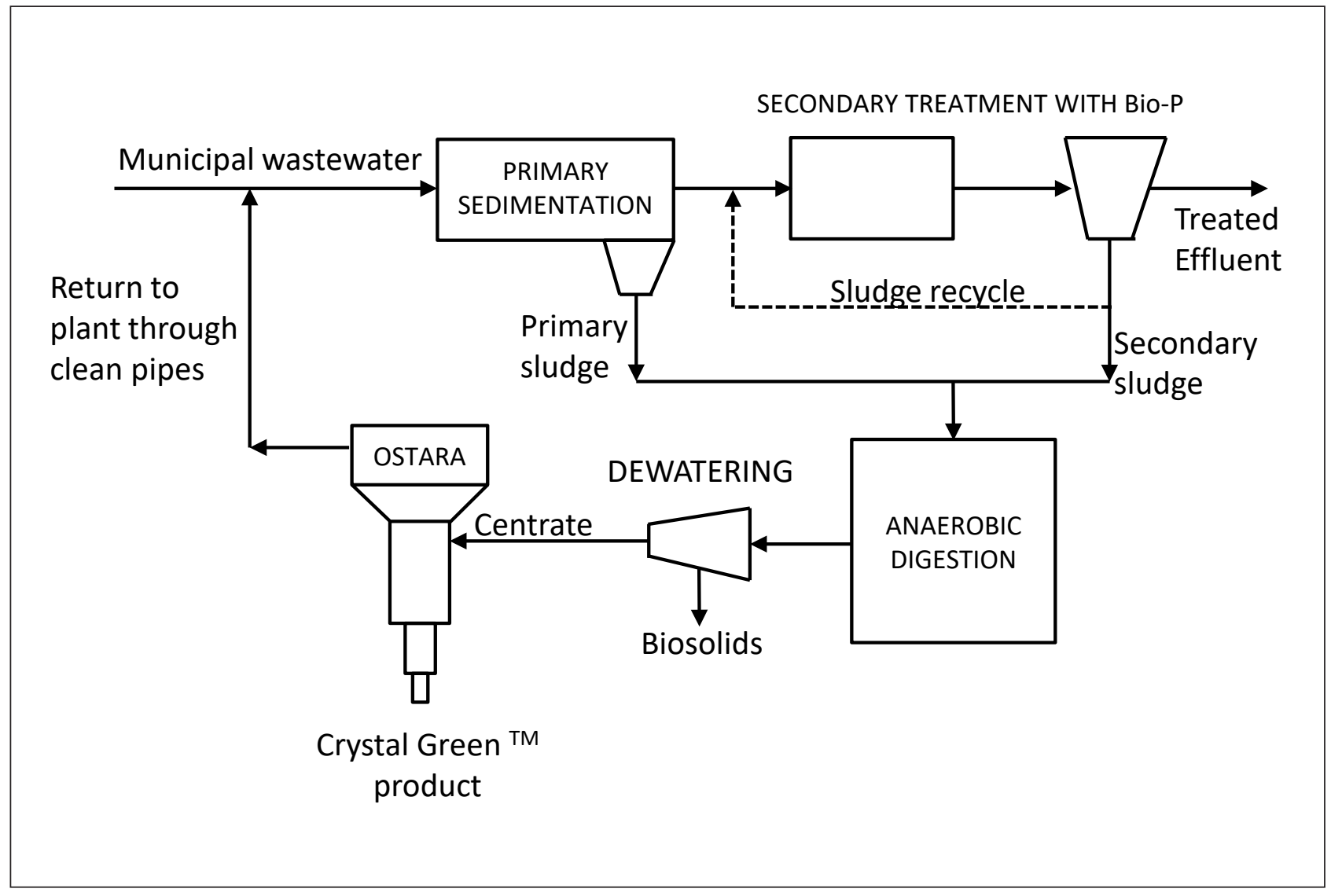

Figure 1

Process diagram describing the Nansemond WWTP (Sikosana et. al, 2014) 


\section{MATERIALS AND METHODS}

Engineering economic assessment methods were used to investigate the potential for centralized recovery of nutrients, through the conceptual design and a techno-economic prefeasibility assessment of two phosphate recovery options at the largest WWTW in the Western Cape, the CFWWTW. The first option considers the recovery of high-grade struvite crystals which is based on the Ostara process, whilst the second produces a lower grade struvite slurry similar to that achieved by Multiform Harvest installations. These options were contrasted with the more traditional chemical precipitation process, a phosphate removal technique commonly practiced in South Africa. During the study, significant fluctuations in process operations were observed. Hence, the process model and technoeconomic assessment were based on theoretical plant data and literature values pertaining to the CFWWTW. The technoeconomic assessment consisted of the following steps:

\section{Concept design}

Concept designs for three phosphate-focused project interventions were developed to assess the potential for struvite production as a viable side-stream treatment option for the CFWWTW. The approach to conceptual design involved:

- Generation of three distinct alternatives, informed by the technology review and analysis of global case studies presented in Sikosana et al. (2014), as well as knowledge of the plant configuration at the CFWWTW

- Development of process flow diagrams and process summaries

- Linking the potential products to the market routes identified in the South African based market assessment described by Sikosana et al. (2014)

\section{Technical assessment (mass and energy balances)}

The high-grade struvite, low-grade and phosphorus precipitation options (described in more detail in the Results section) were then evaluated based on the following key technical criteria (summarized in Table 2):

- Production rate of solid products (kg/d and $\mathrm{kg} / \mathrm{year}$ )

- Energy use (kWh/d)

- Chemical consumption rates $(\mathrm{kg} / \mathrm{d})$

- Plant land requirements $\left(\mathrm{m}^{2}\right)$

- Additional labour requirements (over and above the needs for the existing WWTW)

- Additional maintenance requirements (over and above the needs for the existing WWTW)

\section{Financial assessment}

Based on the struvite production rates and chemical input requirements, engineering economic calculations were used to evaluate the financial feasibility of struvite production at the CFWWTW. The economic viability of struvite production was assessed based on the following economic indicators:

- Plant establishment costs: capital expenditure (CAPEX)

- Operating expenditure (OPEX)

- Cost recovery from struvite production (revenue)

- Net present value/net present costs (NPV/NPC) over a 20-year investment period

Comparison of the three options was made based on the NPV/ NPC values achieved. The economic assessment criteria used in NPV/NPC calculations for all three options are summarized in Table 3.

TABLE 1

Muiltiform harvest compared to Ostara costs for 2010 for the same capacity (adapted from Bilyk et al., 2010)

\begin{tabular}{|c|c|c|}
\hline Service provider & Ostara & Multiform Harvest \\
\hline Installations & 8 full-scale installations & 1 full-scale and 1 pilot \\
\hline Plant land requirements & Needs a new building & $\begin{array}{l}\text { May be retrofitted into existing buildings and plant } \\
\text { structures }\end{array}$ \\
\hline \multirow{4}{*}{ Reactors } & $\begin{array}{l}\text { Conical fluidised bed reactor for crystallisation } \\
\text { process }\end{array}$ & Conical fluidised bed reactor for crystallisation process \\
\hline & $\begin{array}{l}\text { Set reactor sizes that are larger than Multiform } \\
\text { Harvest }\end{array}$ & \\
\hline & $\begin{array}{l}\text { Reactor effluent recycled several times to } \\
\text { achieve high quality } \\
\text { struvite crystals }\end{array}$ & $\begin{array}{l}\text { No recycle and shorter retention time than the Ostara } \\
\text { process }\end{array}$ \\
\hline & $80-90 \%$ recovery & $80-90 \%$ recovery \\
\hline \multirow[t]{2}{*}{ Struvite processing } & $\begin{array}{l}\text { Struvite is processed at the WWTW: drying and } \\
\text { bagging equipment installed at WWTW }\end{array}$ & $\begin{array}{l}\text { Struvite is not processed onsite: no bagging or drying } \\
\text { required }\end{array}$ \\
\hline & High quality crystalline struvite is sold & Low quality (often powdery) struvite is collected \\
\hline Product ownership & $\begin{array}{l}\text { Ostara has the selling rights to the struvite } \\
\text { produced that is marketed as Crystal Green }\end{array}$ & $\begin{array}{l}\text { Multiform Harvest has the selling rights to the struvite } \\
\text { produced }\end{array}$ \\
\hline Maintenance and repair & $\begin{array}{l}\text { High maintenance costs associated with struvite } \\
\text { processing units }\end{array}$ & Lower than Ostara due to reduced equipment \\
\hline
\end{tabular}




\begin{tabular}{|c|c|c|c|}
\hline \multicolumn{4}{|c|}{\begin{tabular}{|l} 
TABLE 2 \\
\end{tabular}} \\
\hline \multicolumn{4}{|c|}{ Design criteria for the technical assessment of all options } \\
\hline Description & Unit & Value & Comment / Source \\
\hline CFWWTW Flowrate & ML/day & 125 & Plant data (average) \\
\hline Side stream DS\% & $\%$ & 3.5 & Plant specifications \\
\hline Side stream flowrate & $\mathrm{m}^{3} /$ day & 1060 & Calculated from maximum design capacity of dewatering centrifuge \\
\hline Side stream pH & & 4.8 & Plant data \\
\hline Phosphate concentration & $\mathrm{mg} / \mathrm{L}$ & $89-190$ & 190 mg/L (Van Rensburg et al., n.d.) \\
\hline Magnesium concentration & $\mathrm{mg} / \mathrm{L}$ & $29-67$ & 67 mg/L (Van Rensburg et al., n.d.) \\
\hline Ammonia concentration & $\mathrm{mg} / \mathrm{L}$ & in excess & Assumed \\
\hline $\begin{array}{l}\text { Moisture content of filtered } \\
\text { struvite }\end{array}$ & $\begin{array}{l}\text { g/g (water } \\
\text { dry Solids) }\end{array}$ & 1.5 & Assumed \\
\hline Temperature & & $25^{\circ} \mathrm{C}$ & Ambient \\
\hline \multicolumn{4}{|l|}{$\begin{array}{l}\text { High-grade and low-grade } \\
\text { struvite options }\end{array}$} \\
\hline Conversion & $\%$ & 90 & (Rahman et al., 2013) \\
\hline Reaction kinetics & $\mathrm{h}^{-1}$ & 7.9 & (Rahman et al., 2013; Ohlinger et al., 2000) \\
\hline $\mathrm{pH}$ & & 8.7 & (Ohlinger et al., 2000) \\
\hline \multicolumn{4}{|l|}{ Phosphorus precipitation } \\
\hline $\begin{array}{l}\text { Molar feed ratio } \mathrm{PO}_{4}: \mathrm{Al} \\
\text { (orthophosphate: aluminium) }\end{array}$ & mol:mol & $1: 1$ & $\begin{array}{l}\text { (Strom, 2006) } \\
\text { (Minnesota pollution control agency, 2006; Lenntech, 2005) }\end{array}$ \\
\hline Reactor conversion & $\mathrm{mol} \%$ & $90 \%$ & (Strom, 2006; Minnesota pollution control agency, 2006) \\
\hline
\end{tabular}

\begin{tabular}{|l|c|c|l|}
\hline \multicolumn{4}{|c|}{ TABLE 3 } \\
\hline Description & Unit & Value & Source/ comment \\
\hline Price of magnesium chloride & $\mathrm{R} / \mathrm{kg}$ & 8.30 & Protea Chemicals, 2014 \\
\hline Price of aluminium sulphate & $\mathrm{R} / \mathrm{kg}$ & 1.16 & \\
\hline Price of electricity & $\mathrm{R} / \mathrm{kWh}$ & 1.00 & $\begin{array}{l}\text { Within range of peak/off-peak } \\
\text { charges from City of Cape Town } \\
\text { (COCT) for commercial users }\end{array}$ \\
\hline Wages & & & Assumed \\
\hline Water & $\mathrm{R} / \mathrm{h}$ & 80.00 & (COCT) website \\
\hline Transport and disposal & $\mathrm{R} / \mathrm{kL}$ & 12.51 & Sikosana et al., 2014 \\
\hline Maintenance costs & $\mathrm{R} / \mathrm{kg}$ & 0.5 & $\begin{array}{l}\text { Chemical precipitation (Tetra } \\
\text { Tech, 2013) }\end{array}$ \\
\hline
\end{tabular}

\section{Sensitivity analysis}

Various assumptions were made for the baseline technoeconomic evaluation. Therefore, it was necessary to consider to what extent variations in process parameters would affect these results and how best they could be controlled. The impact of various parameters on the NPV costs and, hence, feasibility were tested. The most significant parameters were:

- Maintenance costs (as a percentage of CAPEX)

- Retail selling price of struvite fertilizer (high- and low-grade struvite)

- CAPEX (all options)

- Discount rate

These parameters, with the exception of sludge disposal, struvite selling price and discount rate, were varied over a range from $-50 \%$ to $100 \%$ increase and their effects on NPV were compared to the base case.

\section{RESULTS}

\section{Technical assessment}

\section{Concept design}

The CFWWTW anaerobic digester liquor stream has a phosphorus concentration of 89 to $190 \mathrm{mg} / \mathrm{L}$ and magnesium (Mg) ranging from 29 to $67 \mathrm{mg} / \mathrm{L}$ (Van Rensburg et al., 2003), as well as a design flow rate of approximately $1060 \mathrm{~m}^{3} / \mathrm{d}$. Table 4 summarizes the design basis and concept design features for all process options. Figure 2 is a process schematic, illustrating a high-grade struvite production facility. The low-grade struvite and phosphorus precipitation options were designed as variations of this process.

Unlike the Ostara process shown in Fig. 2, the Multiform Harvest process produces a less refined product (20wt\% DS), which is collected from the bottom of the reactor in a skip, retrofitted with a filter. This skip is collected weekly from the 
WWTW and may be further treated off-site before being sold to secondary markets. The conical fluidized bed reactors are typically smaller than the Ostara installations, with a lower retention time, and do not require recirculation pumps. In addition, unlike high-grade struvite, no drying or bagging equipment is required, which drastically reduces capital costs.

\section{Technical assessment summary}

At $90 \%$ conversion, both the high-grade and low-grade struvite options produce approximately $469 \mathrm{~kg} / \mathrm{d}$ of struvite (on a dry basis), recovering $58 \mathrm{~kg} / \mathrm{d}$ of phosphorus. When packaged and dried, this amounts to $510 \mathrm{~kg} / \mathrm{d}$ (92 wt\% dry solids (DS)) high-grade struvite and $568 \mathrm{~kg} / \mathrm{d}$ (80 wt\% DS) low-grade (wet) struvite. Chemical precipitation results in $242 \mathrm{~kg} / \mathrm{d}$ of chemical sludge (aluminium hydroxide + phosphate) and an additional $25 \%$ suspended solids removal (WEF, 2005), to give $601 \mathrm{~kg} / \mathrm{d}$ of dry sludge. Once mechanically dewatered to $25 \%$ dry solids, $2400 \mathrm{~kg} / \mathrm{d}$ excess sludge is to be disposed of. This is an $0.2 \%$ increase in the overall Cape Flats sludge production. Aluminium solution dosage for chemical precipitation is about $2630 \mathrm{~kg} / \mathrm{d}$ which is 5 times that of the magnesium dosing material required for high-grade and low-grade struvite production.

Chemical precipitation generally has a higher energy footprint, but only slightly, than that of low-grade struvite production (Bilyk et al., 2010). High-grade struvite production carries a significant electrical/carbon footprint, which should be ignored. The technical assessment of all three options is summarised in Table 5.

\section{Link to potential markets}

Expert interviews were conducted in a preceding study by Sikosana et al. (2014) to assess the acceptability of phosphate fertilizer production from human waste, as well as the potential markets within the South African context. Three academic experts in struvite production, an organic farming expert, an organic farmer, one representative from retail, and one representative from the fertilizer industry, as well as two representatives from two different organic certification boards, were interviewed, giving a total of nine participants.
It is believed by the industry experts that the South African organic market is immature and its consumer may not be ready for fertilizers produced from human waste, let alone for use of these fertilizers in food production. Higher acceptability could be experienced within the inorganic fertilizer production market, regardless of source, if struvite is proven to be safe and a reliable purification process is identified. More feasible markets could lie within ornamental plant fertilization, commercial fertilizer production and fertilizer use within closed community gardens. Therefore, there is potentially a larger market for lower-grade struvite. Based on these findings, the possible market avenues for high-grade and low-grade struvite, as well as chemical precipitation products, determine and differentiate the market value of these three process products and the calculations to followed.

\section{Economic assessment}

At $90 \%$ conversion, $470 \mathrm{~kg} / \mathrm{d}$ of dry struvite can be produced at a cost of R22/kg struvite for high-grade and R8.90/kg struvite for the unprocessed fertilizer. This production rate recovers $4.2 \%$ and $8.0 \%$ of the operating costs for the low-grade and high-grade struvite options, respectively. Chemical precipitation produces $2400 \mathrm{~kg} / \mathrm{d}$ (25 wt\% DS) excess sludge for landfill disposal. Phosphate removal at the CFWWTW will incur additional treatment costs of R0.05, R0.03 and R0.12 per kilolitre to the business-as-usual rate, for high-grade struvite, low-grade and chemcial precipitation, respectively. In comparison to recovering water for reuse at a cost of R7.00/kL and sewage costs at R2.90/ $\mathrm{kL}$, all options come in cheaper than these costs.

The estimated net present costs are R76.2, R25.4 and R51.1 million for the high-grade struvite, low-grade struvite, and phosphorus precipitation, respectively. Higher operating costs due to chemical dosing and sludge disposal amplify the net present costs of phosphorus precipitation. The high flow rate to phosphate loading ratio makes the high capital cost associated with on-site processing of high-grade struvite impractical. Despite the higher market value, low production rates of highquality struvite will not generate enough revenue to recover the cost of production, let alone the investment. Table 6 compares the economic viability of all three options.

TABLE 4

Key design features of the three concept designs: high-grade struvite, low-grade struvite and phosphorus precipitation

\begin{tabular}{|c|c|c|c|}
\hline & High-grade struvite & Low-grade struvite & Phosphorus precipitation \\
\hline Basis of design & Ostara installation (Ostara, 2013) & $\begin{array}{l}\text { Multiform Harvest (Bilyk et al., } \\
\text { 2011) }\end{array}$ & $\begin{array}{l}\text { Typical installations } \\
\text { (Tetra Tech, 2013) }\end{array}$ \\
\hline Technology & Crystallisation fluidised bed reactor & Crystallisation fluidised bed reactor & $\begin{array}{l}\text { Chemical precipitation stirred tank } \\
\text { reactor }\end{array}$ \\
\hline Objective & $\begin{array}{l}\text { To recover excess orthophosphate } \\
\text { by producing high quality, } \\
\text { crystalline struvite for sale in } \\
\text { premium markets }\end{array}$ & $\begin{array}{l}\text { To recover excess orthophosphate } \\
\text { by producing low quality, powdery } \\
\text { struvite for sale in low end markets } \\
\text { and processing plants }\end{array}$ & $\begin{array}{l}\text { Removal and disposal of excess } \\
\text { orthophosphates in process side } \\
\text { streams }\end{array}$ \\
\hline \multirow[t]{3}{*}{ Process summary } & $\begin{array}{l}\text { Use of large reactor unit with } \\
\text { recycle for high quality crystal } \\
\text { formation }\end{array}$ & $\begin{array}{l}\text { Use of smaller (than Ostara) } \\
\text { reactors to produce a low quality } \\
\text { struvite slurry }\end{array}$ & $\begin{array}{l}\text { Chemicals dosed to induce } \\
\text { precipitation }\end{array}$ \\
\hline & $\begin{array}{l}\text { Struvite is filtered and dried ( } 92 \% \\
\text { dry solids (DS)) }\end{array}$ & No recycling of reactor effluent & Sludge is dewatered ( $25 \%$ DS) \\
\hline & & Collected struvite is (20\% DS) & \\
\hline
\end{tabular}




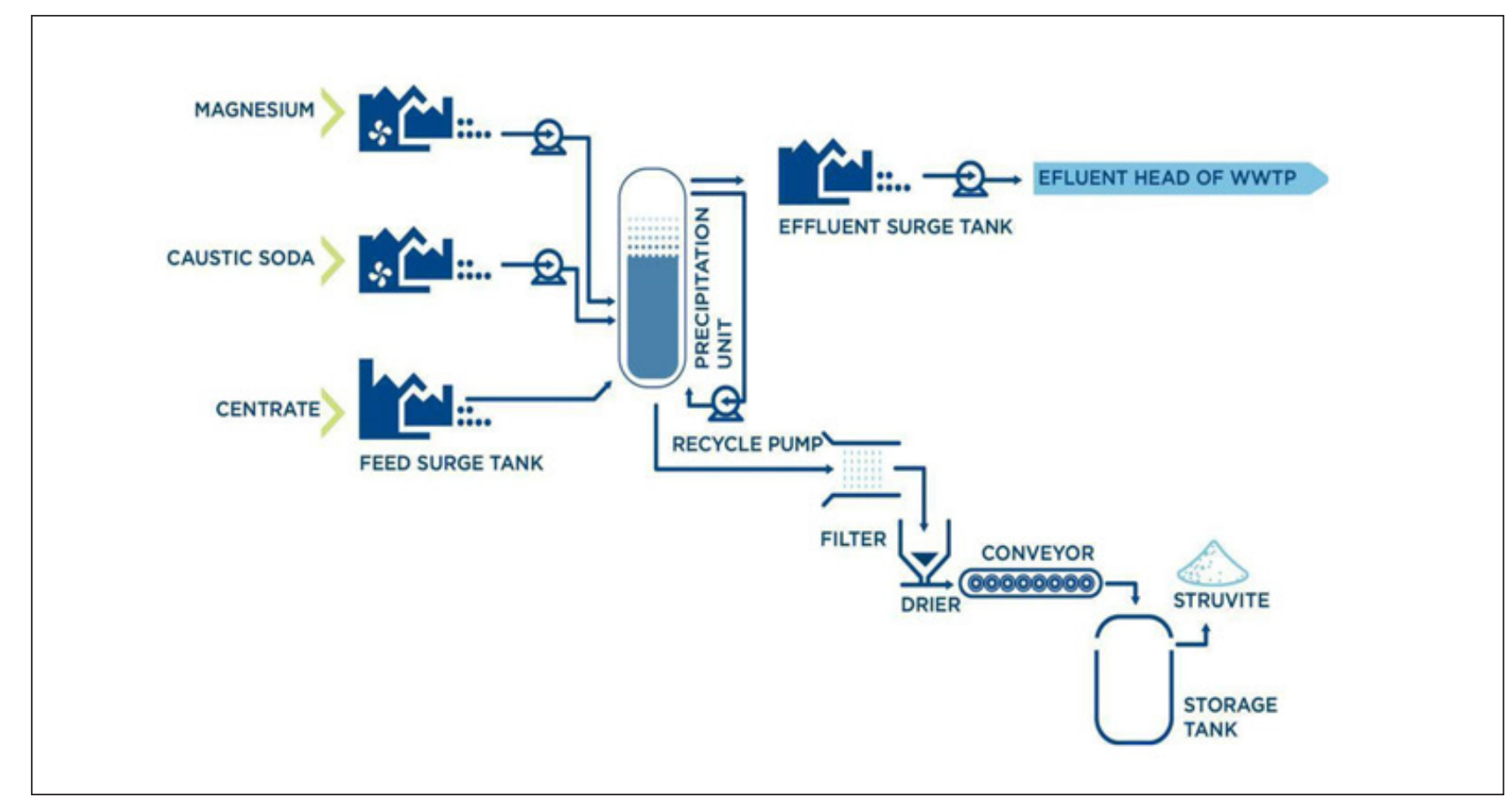

Figure 2

Process description of the Ostara-like nutrient recovery facility to form high-quality struvite, which is processed and packaged on site

\section{Sensitivity analysis}

The base case techno-economic assessment was calculated using approximations, which relied on assumptions, heuristics and literature data. Therefore, it is useful to assess the sensitivity of this assessment to changes in key parameters. This will account for uncertainty in the design criteria and assumptions made. In addition, the main design parameters that could positively affect the feasibility of the proposed options can be identified.

\section{Comparing high-grade struvite and low-grade struvite}

Figure 3 shows the effects of a $-50 \%$ to $100 \%$ increase in selling price, CAPEX and related maintenance costs on the NPV for both high-grade and low-grade struvite production. Changes in high-grade struvite's CAPEX and maintenance drastically influence the NPC. Changes in selling price have very little effect on the overall profitability of the plant in both instances.

\section{Best-case high-grade struvite vs. low-grade struvite}

If the municipality were to consider the production of highgrade struvite over the unprocessed low-grade struvite, key process parameters would have to be adjusted to yield an NPV within an acceptable cost bracket. In this case, the highgrade struvite's NPV is most affected by CAPEX. Thus, if a prefabricated Ostara Pearl 2000 reactor is used instead of a reactor manufactured to the specific design capacity of the CFWWTW, even though it is larger than the required capacity, the NPC of the whole installation may be reduced to R48 million. At best, the high-grade struvite product can be sold at R6.60/kg struvite, resulting in an NPC of R41.4 million; which would be 1.6 times greater than that of the low-grade option. To reduce the cost even further to R32.5 million, maintenance costs could be lowered to the business-as-usual option of $2 \%$. It is evident that unless the phosphate concentration in this CFWWTW side stream increases, low-grade struvite production, based on the Multiform Harvest design, will always come in cheaper than high-grade struvite (Ostara-based design).

\section{Comparing low-grade struvite and phosphorus precipitation}

Figure 4 compares the effects of the low-grade struvite and chemical precipitation NPCs with the change in chemical dosing costs and CAPEX. Chemical dosage costs have the highest effect on the phosphorus chemical precipitation NPC, but has little effect on that of the low-grade struvite process. However, even with a $50 \%$ drop in the chemical price for the traditional precipitation treatment method, low-grade struvite is still a more affordable option for phosphate removal at CFWWTW.

\section{Best-case phosphorus precipitation vs. low-grade struvite}

Key process parameters can be changed in a number of ways and may make phosphorus precipitation and low-grade struvite even more comparable, or at the very best, with NPVs within $10 \%$ of each other. If phosphorus precipitation can use an existing clarifier and belt press for dewatering, the CAPEX value can drop to R0.78 million and consequently the NPC to R50.7 million. At best alum sells for R1.08/kg; this results in a drop in the NPC to R38.6 million, which is now 1.5 times that of low-grade struvite. If possible, the excess sludge may be treated in the thermal drying plant, hence eliminating sludge disposal costs and reducing the NPC to R34.6 million. But even then, the base case design (no parameter changes) of low-grade struvite production is cheaper than phosphorus chemical precipitation over a 20 -year period. In addition, as illustrated by Table 7 , with these parameter changes, phosphorus precipitation comes within $10 \%$ of the high-grade struvite's best-case scenario. In this case high-grade struvite could be cheaper than phosphorus precipitation, but low-grade struvite prodcution would still be the most economical option. 
TABLE 5

Technical summary for high-grade struvite, low-grade and chemical/phosphorus precipitation

\begin{tabular}{|c|c|c|c|}
\hline & High-grade struvite & Low-grade struvite & Phosphorus precipitation \\
\hline Phosphate recovery (\%) & 90 & 90 & 90 \\
\hline Orthophosphate (kg/day) & 178 & 178 & 178 \\
\hline Struvite (kg/d) $(40 \%$ DS) & Wet: 1173 Dry: 469 & Wet: 1173 Dry: 469 & - \\
\hline Package struvite (kg/d) & (8\% DS): 510 & (20\% DS): 568 & - \\
\hline Excess sludge (kg/d) & - & - & Dry: 601 Wet: 2400 \\
\hline Utilities (kWh/day) & 727 & 204 & 159 \\
\hline Plant land requirements $\left(m^{2}\right)$ & 325 & 250 & 77 \\
\hline Chemical dosing (kg/d) & $\mathrm{MgCl}_{2}: 540$ & $\mathrm{MgCl}_{2}: 540$ & Alum: 2630 \\
\hline Employees & 2 & 2 & 2 \\
\hline \multicolumn{4}{|c|}{ Major equipment $\mathrm{m}^{3}$} \\
\hline Fluidised bed reactor & 50.3 & 50.3 or $(2 \times 25)$ & Flash tank: 7.37 \\
\hline Feed buffer tank & 382 & 382 & 382 \\
\hline
\end{tabular}

TABLE 6

Summary of economic assessment for all three options

\begin{tabular}{|l|c|c|c|}
\hline & High grade struvite & Low grade struvite & Phosphorus precipitation \\
\hline CAPEX & 76.5 & 20.6 & 2.49 \\
\hline OPEX & 3.97 & 1.51 & 5.18 \\
\hline Sludge handling R & N/A N/A & N/A \\
\hline Selling price of struvite R/kg & 1.84 & 0.37 & 0 \\
\hline Revenue & 315000 & 63300 & N/A \\
\hline Cost/kg struvite & 22.1 & 9.01 & 86.2 \\
\hline Cost/kg PO recovered (removed) & 56.6 & 23.5 & 263 \\
\hline Cost/kg P recovered (removed) & 173 & 72.0 & 0.12 \\
\hline Treatment cost/kL (influent) & 0.05 & 0.03 & 51.2 \\
\hline Net projected costs (R million) & 76.2 & 25.4 & \\
\hline
\end{tabular}

\section{Discount rate for all three options}

When calculating the NPV over a given period, discount rates apply to and may differ for public, private and publicprivate partnership (PPP) investments. Typically, public sector discount rates are lower, and range between $3 \%$ and $10 \%$ and represent long-term project investments. Private investment or PPP schemes discount rates have been quoted to be as high as $15 \%$, which usually accounts for capital financing (Burger and Hawkesworth, 2011). Figure 5 shows how the NPCs of all three options vary with a change in discount rate from 3-20\%. High-grade struvite production experiences the greatest drop in NPC from R100 million to under R63 million at 20\%. At higher discount rates, low-grade struvite and phosphorus precipitation become more comparable, a R15 million difference in NPV between 15 and $20 \%$. At 5\%, rates more representative of public sector investment, high-grade struvite, low-grade struvite and phosphorus precipitation increase to R90.5, R30.5 and R73.4 million, respectively.

\section{DISCUSSION}

This paper set out to determine whether phosphate recovery technologies are likely to produce a socially acceptable product and what determines their affordability.

In terms of affordability, if a WWTW is to reduce effluent phosphate loading to within legislative standards for environmental discharge, low-grade struvite production using a Multiform Harvest based set-up, has been shown to be the most ecologically and economically sustainable option from a lifecycle-costs perspective. It was found that CAPEX has the highest effect on NPV for both the high-grade and low-grade struvite options, whereas chemical dosing cost significantly affects chemical precipitation. Low-grade struvite is the most affordable and can be profitable within 19 years if the hypothetical selling price of struvite is increased to about R14/kg struvite. Despite optimistic changes in key design parameters for both high-grade (Ostara process) and phosphorus precipitation, a low-grade struvite (Multiform Harvest) process installed at the CFWWTW will always work out cheaper. 


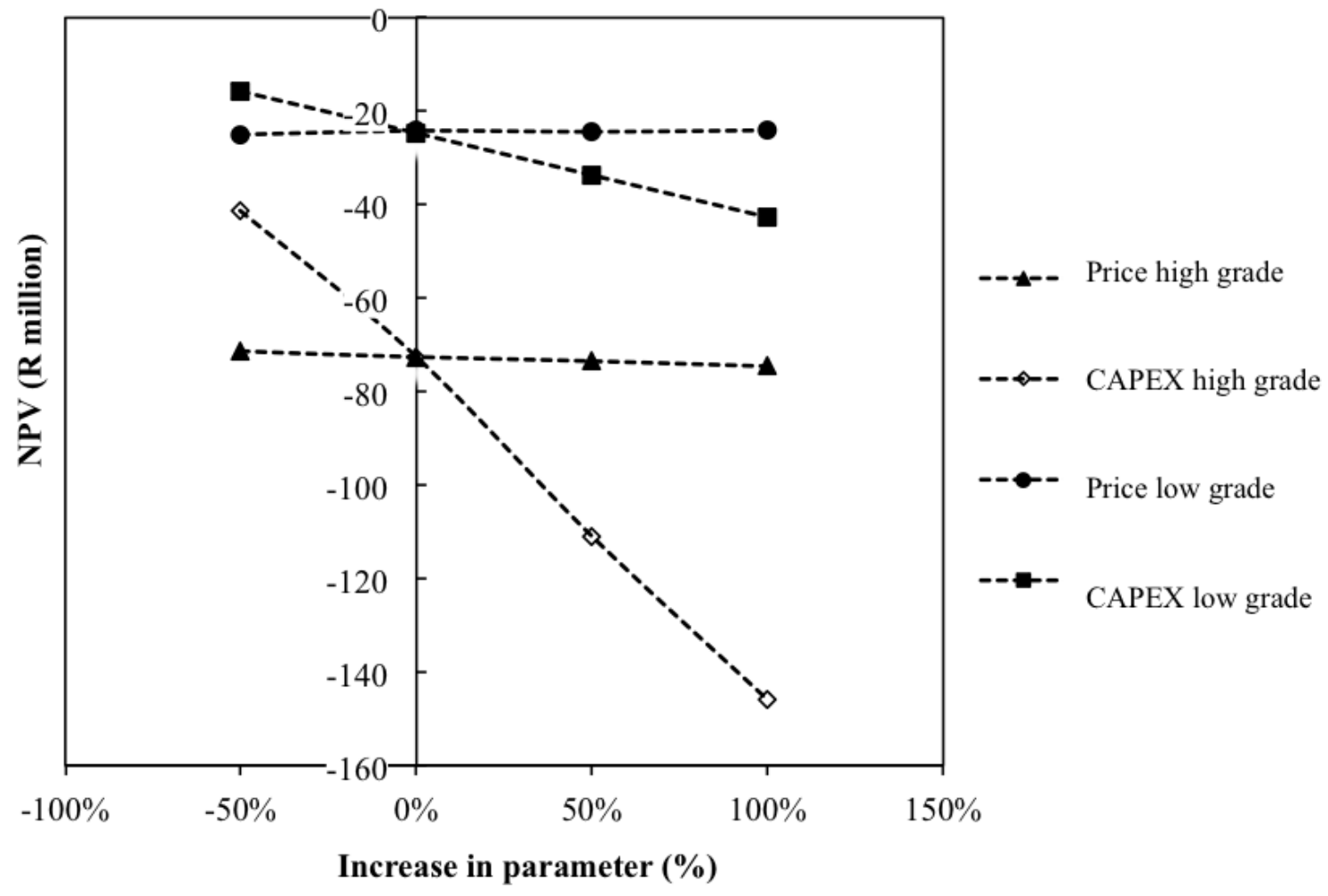

Figure 3

Plot of varying parameters (selling price and CAPEX) to identify key parameters for high-grade and low-grade struvite production processes.

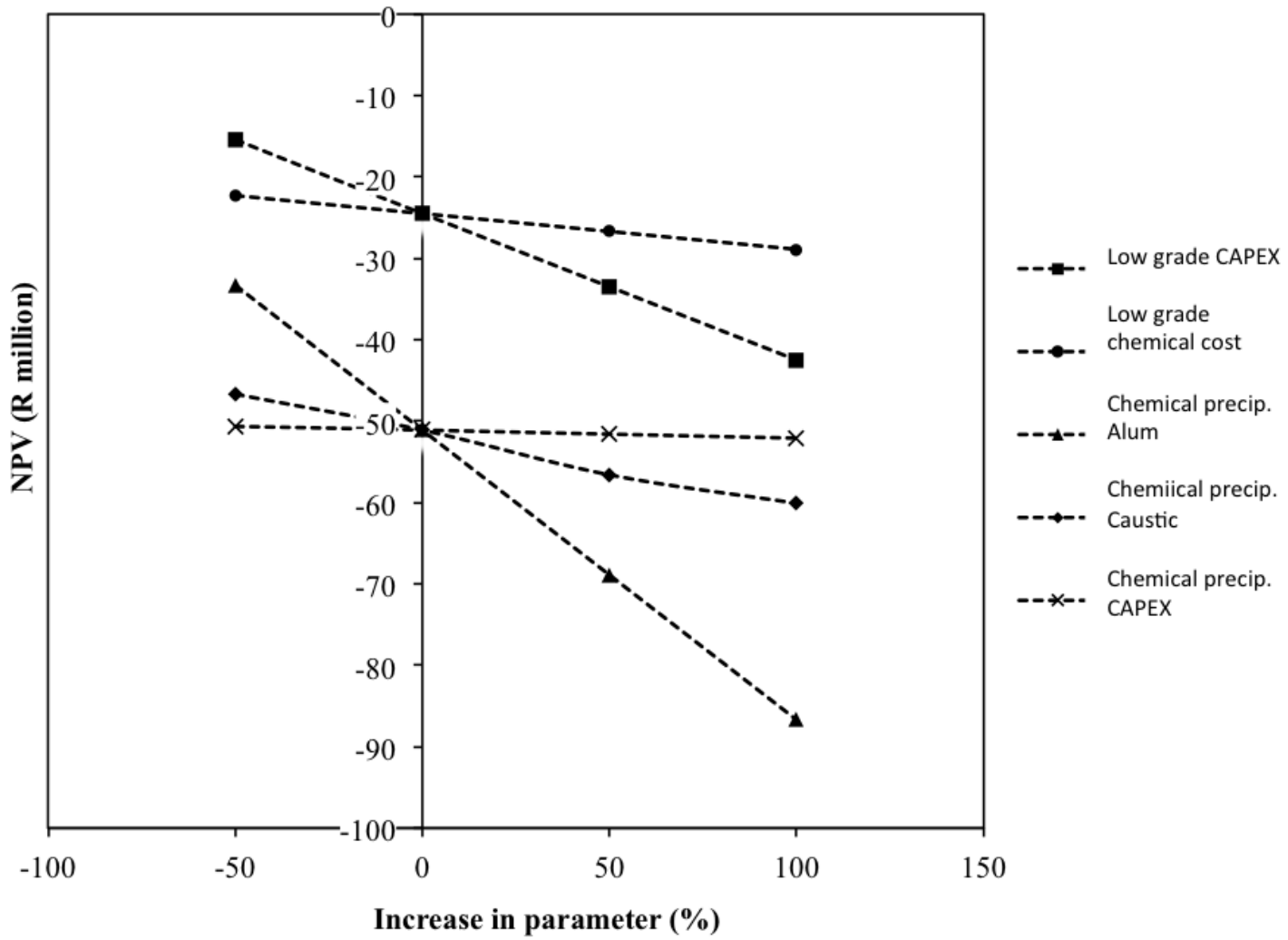

Figure 4

Sensitivity of NPVs to varying chemical costs 
TABLE 7

Comparing the 3 options with a change in key parameters

\begin{tabular}{|l|l|l|l|}
\hline \multicolumn{1}{|c|}{ Option } & \multicolumn{1}{|c|}{ Best case high-grade struvite } & \multicolumn{1}{|c|}{ Low-grade struvite } & $\begin{array}{l}\text { Best case phosphorus precipita- } \\
\text { tion }\end{array}$ \\
\hline Case description & $\begin{array}{l}\text { - CAPEX reduced by using } \\
\text { prefabricated reactors } \\
+ \text { Struvite can sell at the literature } \\
\text { value of R6.60/kg struvite } \\
- \text { Maintenance cost reduced to 2\% }\end{array}$ & No change & $\begin{array}{l}\text { - CAPEX reduced by use of an } \\
\text { existing clarifier and belt press for } \\
\text { dewatering } \\
\text { - Reduce sludge removal costs by } \\
\text { treating excess sludge in thermal } \\
\text { drying plant }\end{array}$ \\
\hline NPC (R millions) & 32.5 & 25.4 & 34.6 \\
\hline
\end{tabular}

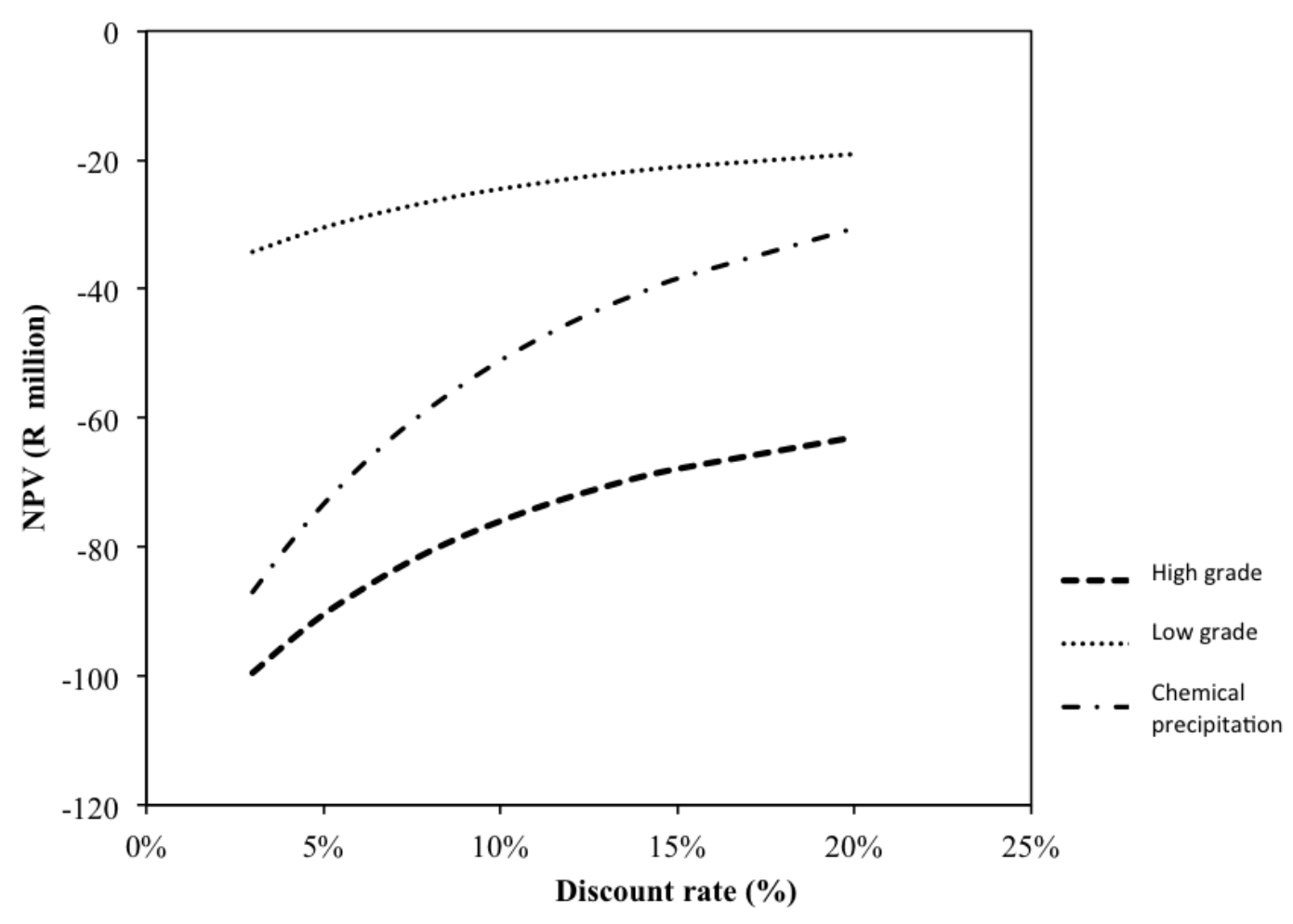

Figure 5

NPV costs with varying discount rate

From a social standpoint, the experts interviewed believe that the South African food market could resist fertilizers derived from human waste, hence potentially ruling in favour of low-grade struvite for use in secondary non-food markets. Although the production of low-grade struvite is a simple process, it is not cheap; the capital investment is 10 times that of South Africa's more familiar chemical precipitation route. Hence, a WWTW will have to consider the environmental benefits over the capital costs, if they are to consider phosphorus recovery instead of the more familiar chemical precipitation option.

\section{Recommendations}

The following theoretical and policy implications should be considered:

1. A shift is required to more sustainable wastewater treatment techniques: Although common and affordable, chemical precipitation incurs significant costs and diverting the phosphate from wastewater to solid waste merely shifts the environmental burden. Policy that bars sewage sludge disposal to agriculture as of 2015 (CDM Executive Board, n.d.), seen against increasingly limited landfill space, already has decision-makers exploring new options for sludge treatment and disposal.

2. Implementing low-grade struvite treatment is a beneficial alternative to current methods, from an environmental point of view: Similar to findings by Bilyk et al. (2010), low-grade struvite production is the cheapest of the three options investigated. Despite having the most attractive economics, local municipalities may find it hard to justify the high capital investment and unprofitable operations. When compared to most struvite production case studies, which have shown profitable outcomes within the 20 -year period, struvite production from the current CFWWTW will not be profitable. However, this option does fall within the global cost bracket for struvite production at R8.90/kg struvite and 
may be justified from this angle. Municipalities will have to consider the environmental benefits over the costs.

3. Identify and quantify the implications of phosphate recovery on other plant activities at the CFWWTW: Sidestream treatment does not only reduce nutrient discharge into surrounding water bodies, but affects overall plant performance - in this case, nutrient concentrations typically received by both the secondary treatment and thermal drying plant will be affected. It is therefore essential to obtain more detail on such plant effects from installations globally and integrate these findings into a model for local WWTWs.

4. Phosphate loading to flow rate ratio affects profitability: High CAPEX associated with high-grade struvite production makes this the most costly choice, especially as the South African market may be better suited to lower-grade struvite production. However, this process only marginally increases treatment costs to R1.42/kL, which is cheaper than both the wastewater recycling for reuse $(\mathrm{R} 7.00 / \mathrm{kL})$ and sewage costs (R2.90/kL).

5. Wastewater may not be the 'right' phosphate stream to concentrate on in South Africa: Other WWTWs with a higher phosphate loading to flow rate ratio may yield economics in favour of high-grade production. However, one may need to consider the substantial electrical/carbon footprint. Even then, relative to phosphate run-off on farms and other urban sinks, the small amount of nutrients extractable from the wastewater profile makes it technically and economically difficult to justify. Mapping of an economy-wide phosphate pathway may identify larger sinks - organic matter sent to landfills may have more potential, especially as organic waste processing is at its infancy in South Africa.

6. There is space for innovation: The CAPEX for struvite production is substantial. Locally constructed reactors, with improved kinetics, might be cheaper than both the Ostara and Multiform Harvest installations and may lead to both funding and research opportunities in South Africa.

7. Change phosphate policy to address scarcity rather than just pollution: Although progressive, the recent South African legislation limiting effluent phosphate to $1 \mathrm{mg} / \mathrm{L}$ treats phosphate as a nuisance rather than an essential resource. Policy could be modified to promote the reduction, reuse and recycling of phosphate; this would inherently tackle the pollution issue. The Nutrient Credit Trading system described by Algeo and O'Callaghan (2013) is an example of such a policy.

8. There are other South African market considerations: Government does not regulate the fertilizer markets. Both struvite processes were shown to be unprofitable, partly due to the low struvite prices, which are subject to South African phosphate fertilizer prices on the local market. As such, fertilizer policy and price regulations would help to better understand the placement of struvite in the fertilizer market. In addition, this could increase fertilizer prices to values more comparable to the global market.

\section{CONCLUSIONS}

This paper set out to compare three options for meeting phosphate discharge limits at a large biological wastewater treatment works in Cape Town, South Africa. Two options for phosphate recovery (high-grade vs low-grade struvite) were compared to conventional phosphate removal by chemical precipitation using metal salts. The main findings are that:

- The net present costs for high-grade, low-grade and chemical precipitation installations at the Cape Flats Wastewater Treatment works (CFWWTW), discounted at $10 \%$ over a 20-year period, were R76.2, R25.4 and R51.2 million, respectively: low-grade production suited for secondary markets is cheapest, regardless of key parameter changes

- Chemical precipitation CAPEX is the lowest and is within the allocated budget for the planned CFWWTW upgrade.

- WWTWs with a higher phosphate loading to flow rate ratio may yield better economics.

- Struvite will have to establish its own niche market, because the current phosphate market price in South Africa is too low to offset the costs of phosphate recovery.

- New policies for phosphate recovery require a paradigm shift in viewing phosphate, from a nuisance in WWTW to a valuable resource.

\section{Limitations}

This research used standard engineering techno-economic methods to assess and contrast three conceptual retrofit designs for phosphate recovery/removal, using data collected from various literary sources. Although plant samples and experimental work would have been preferred, plant irregularities at the CFWWTW made it difficult to attain trustworthy data. As such, this work is limited by the availability and reliability of the CFWWTW's reported data as well as the 'engineering' assumptions made. However, the results were scrutinized under a large degree of uncertainty, presented in the sensitivity analysis; thus this method provides decision makers with reasonable cost estimates, for comparing potential WWTW nutrient recovery projects.

\section{ACKNOWLEDGEMENTS}

The authors would like to gratefully acknowledge the Water Research Commission of South Africa for the financial support provided, for both this work and the associated project (WRC $\mathrm{K} 5 / 2218 / 3$ ). Ms Carol Carr was instrumental in ensuring that this funding was rightfully allocated. Further gratitude is expressed to Kevin Samson from the City of Cape Town, Lesiba Matlala and co-workers at the Cape Flats WWTW for welcoming us and allowing for the research to be conducted on site. In addition, we would like to thank the industry experts for their participation in the interviews to establish views on fertilizer markets and social acceptance.

\section{REFERENCES}

AFRISCO (2012) AFRISCO Organic Standards. URL: http://www.afrisco. net/ (Accessed August 2013).

BARAK P and STAFFORD A (2006) Struvite: A recovered and recycled phosphorus fertilizer. In: Aglime \& Pest Management Conference, 17-19 January 2006, University of Wisconsin.

BILYK K, PITT P, TAYLOR R and WANKMULLER D (2011) Process and economic benefits of sidestream treatment. Hazen and Sawyer Environmental Engineers and Scientists. 
BOWERS K (2011) Phosphorus removal by struvite precipitation. In: Manure Technology Workshop, 8 March 2011, Ohio. OCAMM, Ohio. CABEZA PEREZ R, STEINGROBE B, ROMER W and CLAASSEN N (2009) Plant availability of P fertilizers recycled from sewage sludge and meat and bone meal in field and pot experiments. In: International Conference on Nutrient Recovery from Wastewater Streams. 10-13 May 2009, Vancouver. IWA publishing, Vancouver.

CDM EXECUTIVE BOARD (n.d) City of Cape Town Treatment of Organic Waste Streams. CDM Projects. United Nations Framework Convention on Climate Change (UNFCCC)/Convention-Cadre des Nations Unies sur le Changement climatique, (CCNUCC) Cape Town.

ETTER B (2009) Struvite recovery from urine at community scale in Nepal. Project intermediate report. Eawag, Nepal.

GANROT Z (2005) Urine processing for efficient nutrient recovery and reuse in agriculture. $\mathrm{PhD}$ thesis, Goteborg University, Goteborg.

GELL K, DE RUIJTER F, KUNTKE P, DE GRAAFF M and SMIT A (2011) Effectiveness of struvite from black water and urine as a phosphorus fertilizer. J. Agric. Sci. 3 3. https://doi.org/10.5539/jas. v3n3p67

JOHNSON AE and RICHARDS IR (2003) Effectiveness of different precipitated phosphates as phosphorus sources for plants. Soil Use Manage. 19 (1) 45-49. https://doi.org/10.1111/j.1475-2743.2003. tb00278.x

KALMYKOVA Y, HARDERR R, BORGESTEDT H and SVANANG I (2012) Pathways and management of phosphorus in urban areas. J. Ind. Ecol. 16 (6) 928-939. https://doi. org/10.1111/j.1530-9290.2012.00541.x

KILIMOHAI ORGANIC (2007) East African Organic Products Standards. Kilimohai Organic, Dar es Salaam.

LENNTECH (2005) Phosphorus removal from wastewater. PRW 2004/05 URL: http://www.lenntech.com/phosphorous-removal.htm (Accessed 10 January 2014).

LIU Y, VILLALBA G, AYRES RU and SCHRODER H (2008) Global phosphorus flows and environmental impacts from a consumption perspective. J. Ind. Ecol. 12 (2) 229-247. https://doi. $\operatorname{org} / 10.1111 / \mathrm{j} .1530-9290.2008 .00025 . x$

MINNESOTA POLLUTION CONTROL AGENCY (2006) Phosphorus treatment and removal technologies. (Brochure). Minnesota Pollution Control Agency, Minnesota.

OHLINGER KM, YOUNG TM and SCHROEDER ED (2000) Kinetic effects on preferential struvite accumulation in wastewater. Environ. Eng. J. 125

RAHMAN M, MOHD.SALLEH M, RASHID U, AHSAN A, HOSSAIN A and RA C (2013) Production of slow release crystal fertilizer from wastewaters through struvite crystallization - A review. Arab. J. Chem. 7 55-139.

SCHRÖDER JJ, CORDELL D, SMIT AL and ROSEMARI A (2009) Sustainable use of phosphorus. Report 357. Plant Research International, Wageningen.

SIKOSANA MK, VON BLOTTNITZ H, RANDALL D and PETRIE

D (2014) Nutrient and energy recovery from sewage: Technology review and exploration of possibilities in South Africa. WRC Report No. K5/2218. Water Research Commission, Pretoria.

SMITH JA and OSBORN M (2007) Interpretative Phenomenological Analysis. In Smith J (ed.) Qual. Psychol. 53-80. https://doi. org/10.4135/9781446207536.d10

STROM PF (2006) Technologies to remove phosphorous from wastewater. Water Rutgers.URL: http://www.water.rutgers.edu/ Projects/trading/p-trt-lit-rev-2a (Accessed 4 April 2013).

TETRA TECH (2013) Cost estimate of phosphate removal at wastewater treatment plants. Technical support document. United States Environmental Protection Agency, Washington DC.

TUROVSKIY IS and MATHAI PK (2006) In: Wastewater Sludge Processing. John Wiley \& Sons Inc., New Jersey, USA.

UNEP (United Nations Environment Programme) (2001) Environmentally sound technologies in wastewater treatment for the implementation of the UNEP Global programme of Action (GPA). Guidance on Municipal Wastewater. UNEP, Perth.

UNEP (United Nations Environment Programme) (2007) Organic agriculture in Africa. URL: http://www.unep.org/training/ programmes/Instructor\%20Version/Part_2/Activities/Human_ Societies/Agriculture/Supplemental/Organic_Agriculture_in_Africa. pdf (Accessed 3 March 2014)

VAN RENSBURG P, MUSVOTO EV, WENTZEL MC and EKAMA GA (2003) Modelling multiple precipitation in anaerobic digester liquor at the Cape Flats Sewage Treatment Plant. In: Water Institute of Southern Africa (WISA) Biennial Conference \& Exhibition, Cape Town, 2-6 May 2003. Advanced transformation technologies, Cape Town

Valorisation of Urine Africa (VUNA) (2013) Urine fertilizers Greenhouse trials with struvite and nitrified urine. Promoting sanitation and nutrient recovery through urine separation. (Brochure). VUNA, Durban.

Water Research Environment Roundation (WERF) (2005) Chemical phosphorus removal. In: Biological Nutrient Removal (BNR) Operation in Wastewater Treatment Plants. McGraw-Hill Professional, Alexandria, VA, USA.

WILSENACH JA (2003) An overview of initiatives in Europe to recover phosphate from source separated urine. Overview. Delft University of Technology, Delft. 